\title{
ASPECTS OF THE HISTORICAL GENESIS OF THE ENERGY SECTOR OF REPUBLIC OF MACEDONIA AND THE CHANLLENGES OF ITS DEVELOPMENT
}

\author{
Serjoza Markov
}

https://doi.org/10.31410/itema.2018.549

\begin{abstract}
Energy is a key topic of our time, something that is not at all surprising if we take into account the fact that energy lies in the basis of the development of the overall modern civilization. However, the time we live in adds new aspects and contexts to this topic, making the role of energy more essential, and energy planning more complex.

The question that arises as the basis of this paper is how the development of the power system takes place on the territory of the Republic of Macedonia? Has Macedonia timely followed the new achievements in the electricity sector and has it developed sufficiently to influence the development of the economy? Is Macedonia ready to adapt its legislation to the European one? This paper aims to briefly answer the questions thus asked. The goal is to summarize in one place all the theoretical and empirical aspects of the emergence and development of electro energetics in the Republic of Macedonia. Although the realization of this goal is of great importance to the power sector as one of the most significant in each country, it especially adds weight, having in mind its functional connection with the development of the overall economic standard in one state.

From here, the energy sector is on the pedestal in an economic entirety, and its development is essential for the overall progress of a state, as well as for improving the living standard of citizens.
\end{abstract}

Keywords: energy sector, Macedonia, development

\section{Introduction}

7 he Electricity represents a specific, characteristic phenomenon of itself, which is considered one of the most important inventions of mankind and serves exactly to the mankind or to satisfy human needs. Electricity is used as the main source of energy worldwide; hence the existence of developed capacities for generating electricity, as well as an efficient transmission and distribution network is of great importance. The construction of the first DC power station in Paris in 1880, which served to illuminate a limited area in the city, was a real boom in the field of electricity in the last two decades of the 19th century. Further development continued with the construction of the Edison Power Plant in New York in 1881, in London in 1882, in Berlin in 1883. ${ }^{204}$ In 1886 the first AC power station was built in Rome. ${ }^{205}$ The development of the field of electricity does not stop here. What follows was a period of ingenious inventions by Nikola Tesla. Inspired by Tesla's patents, in 1895 in Niagara, the United States, the first hydroelectric power plant was built and this power station distributed electricity at a distance of $35 \mathrm{~km}$ to the city of Buffalo, where it was used by the aluminum industry. ${ }^{206}$ The very construction and beginning of work of this hydroelectric power plant

\footnotetext{
204 povijest.hr/nadanasnjidan/prva-edisonova-elektricna-mreza-u-new-yorku-1882/

205 ibid

${ }^{206} \mathrm{http}: / / w w w . t e s l a . o r g . r s /$ locations/hidroelektrana-na-nijagarinim-vodopadima
} 
represents the beginning of the revolution of the electrification of the world. At this point the need that arisen was the need for legal regulation in this area and establishment of certain rules and principles according to which the energy sector of a country will function, and all of this was to be directed in context of a progress and development of the energy sector, energy capacities and energy law. The energy sector as a segment of every country is the leading force of every industry, and therefore the development of the energy sector is of great importance for every society. As a dynamic branch of the energy sector, the development of the electricity market is one of the main factors for successful established energy sector, and in general, on a global level, every state is working hard on continuous development and advancement of the electricity market.

As an issue that has arisen in recent years, and has been questioned since the beginning of the 1990s until today, is the question of the development of the energy sector in Macedonia. In order to give a clear picture of the extent to which the energy sector of Macedonia has been developed and the level of success it is at, it is necessary to give a historical overview of the events that mark the electrification of the world, mark the development of the energy, the energy sector, and certainly the electricity market. What the electrical power system of Macedonia represents today is mainly due to the accomplished development of the system, starting from the liberation of Macedonia until today. Most certainly, this is a very long period, but it is very important to emphasize all that has been achieved in the development of the system because its development is essential for the overall progress of the country, as well as for improving the living standard of the citizens.

\section{Electrification of Republic of Macedonia}

\subsection{The beginnings of electrification in Republic of Macedonia}

The supply with electricity of Macedonia as a dynamic process began to occur in the period between 1909 and 1944. The first lamp in Macedonia was lit in 1909 in Skopje when the first steam electric power station was built, and in that period Macedonia was still part of the Turkish Empire. Interesting fact is that the small diesel power plant that enabled all this, supplied a pumping station for the city water supply, illuminated the City Hall, one street and the mansion of the Turkish Governor (vali). ${ }^{207}$ Furthermore, the electrification was implemented in other cities and it was carried out independently and separately. The need of legal regulation of the energy field has emerged since this period. Therefore, one of the more important problems that the then-city municipal administration was dealing with was the lighting of the city. A document from that time states that on the basis of Article 254 of the Law on Punishments, the Skopje municipality made several decisions and resolutions aimed at better resolving of the issue of city lighting. ${ }^{208}$ On March 29, 1871, the City Municipality of Skopje adopted a Decision, obliging all pilgrims to light their inns all night, and as a consequence of noncompliance with this decision, the Municipality applied Article 254 of the Law on Penalties which foresaw a penalty of one up to five Turkish coins" ${ }^{209}$ Therefore we can conclude that the energy as a complex branch needed to be regulated legally in order to be used properly. Following the supply with electricity of Skopje, the electrification of the second city, Bitola, took place, but much later i.e. in $1924 .{ }^{210}$ Further, by 1930, Tetovo, Veles, Kumanovo, Shtip, Kriva Palanka, Gevgelija, Vinica and Kocani were supplied with electricity. In the period from

\footnotetext{
${ }^{207} 60$ years electrification of Skopje (Skopje, Electro-Macedonia -generation and distribution plant Skopje)

${ }^{208} 60$ years electrification of Skopje (Skopje, Electro-Macedonia -generation and distribution plant Skopje) 209 ibid

${ }^{210}$ Bushi, Lazo, The Electrical Power in Republic of Macedonia, Struga, 2004, pp. 134-135
} 
1931 to 1935, Prilep, Kicevo and Demir Kapija were supplied with electricity, and from 1936 to 1940, Gostivar, Ohrid, Strumica and Probistip were supplied with electricity. That period is characterized by the fact that electricity was generated in small hydro power plants, but there were also coal and diesel power plants. The main reasons behind the slow electrification of these parts of the world were the feeble economic growth, underdeveloped industry, and it should be noted that, at the time, Macedonia was not an autonomous state, but a merely a province of foreign kingdoms and empires. In the period before World War II, the most important generating facilities that were built were: HPP "Pena" built in 1927, Diesel Power Plant in Skopje built in 1933 and HPP "Matka" built in 1938. ${ }^{211}$

\subsection{Period after the World War II}

The development of the electric power system continues in the period from 1945-2005, which begins immediately after the end of World War II when the "Federal Power Supply Company" (FEP) was established for Macedonia and it managed all the power supply resources in the country. Unlike the previous period when each city experienced its own independent and separate power supply development, FEP for Macedonia operated as a sole company for the entire territory of Macedonia within Federal Yugoslavia. As time passed, the Company's names changed: "FEP for Macedonia" until 1954, "Power Supply Community of Macedonia" until 1966, "Electro Macedonia" until 1990, "PE Power Supply Company of Macedonia" until 2005 and, following the separation and the rebranding the name "EVN Macedonia AD"- Skopje came into use. ${ }^{212}$

In fact, as such established company marked the beginning of the "Power Supply Company of Macedonia", whose continuity, through various organizational forms, has been kept to this day. In order to implement the electrification, a Department for Electrification was formed in the then Ministry of Industry of the Federal government of at that time Democratic Federal Republic of Yugoslavia. ${ }^{213}$

In the post-war period, the Republic of Macedonia functioned as an integral part of the former Yugoslav Federation and that marked the second developmental phase in the electricity sector. The connections in the field of the energy sector were mainly directed towards the former Yugoslav republics and provinces, and at the central level, the government negotiated connections for exchange, import-export of electricity with the neighbors who at that time were bordering the Socialist Republic of Macedonia, namely Bulgaria, Greece and Albania.

The period after the war was a renewal period of the electric power facilities that were badly damaged or destroyed in the war and this became a primary and comprehensive task that was successfully implemented with the assistance of the state and the citizens in the post-war period in Macedonia. The electrification of Macedonia was almost completely realized and the electricity became part of an everyday life in almost all cities and villages throughout the country. The construction of the entire distribution grid, transformer stations and new energy facilities that had the capacity to meet the electricity needs of households and the growing industry took systematic and strenuous efforts.

Due to the fact that during this period from 1945 to 1990, Macedonia's power supply system was an integral part of the former Yugoslavia's power supply system, its development took place as part of the development of the entire power supply system of the former Yugoslavia.

\footnotetext{
${ }^{211}$ Ibid pp. 135

${ }^{212} 60$ years electrification of Skopje (Skopje, Electro-Macedonia -generation and distribution plant Skopje)

213 Bushi, Lazo, The Electrical Power in Republic of Macedonia, Struga, 2004, pp.139
} 
The most important generating facilities of electricity that were built during this period are: TPP Madzari (1949), HPP Mavrovo (1957), HEC Tikvesh (1968), HPP Globochica (1965), HPP Spilje (1969). ${ }^{214}$ At the end of the 70's, the following thermal power stations were built: TPP Negotino (1978), and two years later MEC Oslomej (1980), as well as successively the three thermal plants in MEC Bitola (1982), and the construction of the last plant ended in 1988. Interesting fact is that even today, the largest thermal power plant in Macedonia is TPP Bitola.

\section{Development of contemporary electric power system}

The Macedonian Power Supply Company began the establishment of a modern power supply system sometime in the beginning of the eighth decade of the previous century and this process continues to this day. When the Former Yugoslavia broke apart and Macedonia gained its independence, the country was disconnected from the high-voltage grid of the rest of SFRY. As a result, the Macedonian power supply system itself became autonomous as well and despite all of the hardships it faced, it managed to avoid any major difficulties in supplying electricity to the customers.

Until then, the single company "AD Power Supply Company of Macedonia" in 2005 split into three companies, namely "AD ELEM" - a company which was intended for power generating; "AD MEPSO" - a company whose main activity was the power transmission and "ESM AD" - a company that operated the power distribution.

The transformation of the company "AD Power Supply Company of Macedonia" Joint Stock Company for power generating, transmission and distribution, in state ownership, meant its reconstruction. The reconstruction of "AD Power Supply Company of Macedonia" and the process of privatization of AD ESM and / or the companies established by it, was performed on the basis of a previously adopted decision, i.e. other acts related to the process of transformation, enacted by the Government of the Republic of Macedonia and based on the principles of transparency, non-discrimination, objectivity and in accordance with market conditions, and in reference to the Law on Transformation of Power Supply Company of Macedonia, Joint Stock Company for power generating, transmission and distribution in state ownership. ${ }^{215}$

\section{Establishment and development of ELEM}

The company AD ELEM was created by a Decision of the Government of Republic of Macedonia registered under No. 19-2626/ 1 dated June 30, 2005, for restructuring of the Power Supply Company of Macedonia, Joint Stock Company for Power Generating, Transmission and Distribution, in state ownership, Skopje, with the establishment of a new company for the power generating. ${ }^{216}$ This company is part of the Power Supply Company of Macedonia, Joint Stock Company for power generating, distribution and supply in state-ownership. In the context of this, the company operated and participated in legal transactions under a company title: JP Power Plants of Macedonia, state-owned, Skopje or abbreviated: AD ELEM. The main activity performed by AD ELEM is power generating.

\footnotetext{
${ }^{214}$ Bushi, Lazo, The Electrical Power in Republic of Macedonia, Struga, 2004, pp.141

${ }^{215}$ Law on transformation of Power Supply Company of Macedonia, Joint Stock Company for power generating, transmission and distribution in state ownership, Official Gazette of RM 19/2004

${ }^{216}$ Bushi Lazo, The Perspectives of the electric power in Republic of Macedonia, Struga 2005, pp.100
} 
ELEM is inextricably linked to the development of the energy sector in the Republic of Macedonia, especially from the aspect of the development of power generating in Macedonia. Its operation and its generating facilities date from the beginning of the 20th century, in 1909, when the first light in Skopje was lit. ${ }^{217}$ Its role in power generating is related to the construction of generating facilities. In the period prior to its independence, ELEM implemented a Project for revitalization of hydroelectric power plants in the Republic of Macedonia, which project took place in two phases. The first phase covered the period from 1998-2004, while the second phase covered the period 2010-2014. The benefits that were expected from this Project were as follows: increase of installed capacity, increase of hydro production, reduction of operating costs and reduction of occurrence of power outages.

For the purpose of performing the energy activity: power generating, on 18 November 2005, the Energy Regulatory Commission of the Republic of Macedonia adopted a decision granting ELEM a license to perform the energy activity: power generating.

\subsection{Establishment and development of MEPSO}

According with the Law on Transformation of the Power Supply Company of Macedonia from 2004, MEPSO or Macedonian Electricity Transmission System operator AD was established by a decision of the Government of the Republic of Macedonia and it was established as a trading company that acts as an operator of the electricity transmission system in the Republic of Macedonia.

MEPSO manages the transmission grid with a total length of $2091 \mathrm{~km}$ and thus our transmission system is connected to the electrical transmission systems of the Republic of Bulgaria, the Republic of Greece and the Republic of Serbia. ${ }^{218}$ It is important to note that MEPSO is a member of the European Association of System Operators ENTSO-E.

The trade company MEPSO was registered in the Trade Register of the competent court in Skopje on December 31, 2004, and with its registration, the transformation of Power Supply Company of Macedonia and the process of liberalization of the power system in the Republic of Macedonia was officially and formally started. MEPSO is established as a state-owned company and the Government of the Republic of Macedonia is the founder and sole shareholder. ${ }^{219}$ With the establishment of MEPSO and the division of the activities into electricity transmission and control of the electricity transmission system by ESM, the process of liberalization of the power system of the Republic of Macedonia started to be implemented in practice, and this happened because by division of those public activities. The monopoly of ESM on all activities in the power system of our country ceased to exist. At the establishment of this company, all the organizational units that were united in "Power Transmission", the National Dispatch Center (NDC) of "Power Supply Company" (ESM), as well as the services for development, investments and realization of projects for upgrading of the transmission grid, became part of this company. ${ }^{220}$ The function of "Power Transmission" was to unite the business operations for maintenance, modernization, planning and expansion of the transmission grid, and NDC managed the national power system. Through the unification of these units, MEPSO provided the continuity of Power Transmission - a company for electricity

\footnotetext{
$217 \mathrm{http}: / /$ www.elem.com.mk/?page_id=318

218 http://mepso.com.mk/

${ }^{219}$ Bushi Lazo, The Perspectives of the electric power in Republic of Macedonia, Struga 2005

${ }^{220} \mathrm{http}$ ://mepso.com.mk/
} 
transmission and transformation, a company established by the Decision of the Executive Council of SR Macedonia on December 31, 1958 under the name "Electro Jug".

Main activity of the MEPSO's operation is provision of unobstructed transmission of electricity through the transmission and management of electric power system, all of which would enable reliable supply of consumers with quality electricity. MEPSO owns two licenses issued by the Energy Regulatory Commission, one for the Transmission System Operator and the other for the Electricity Market Operator.

MEPSO has constantly been developing through the years as a company that performs activities of public interest-transmission of electricity and organization and management of the electricity market in the Republic of Macedonia, and as such company it is constantly working to optimize its capacities and resources in order to provide quality public service for all users and citizens in general.

Therefore, MEPSO constantly worked on developing the activity in terms of legal regulations, continuous improvement of all processes and monitoring of the satisfaction of its users, creation and maintenance of working atmosphere, constant and planned education and training, constant improvement of the relationship and development of partnerships with associates, risk assessment and opportunities in their business, etc. In fact, the electricity market in the Republic of Macedonia has been established by MEPSO.

More specifically, the Electric Power Market Operator (EMO), as a working unit of MEPSO, in accordance with the Energy Law and the license for organizing and managing the electricity market, is responsible for organizing and management of the electricity market in accordance with the principles of publicity, transparency, non-discrimination and competitiveness.

\subsection{Establishment and development of ESM AD}

ESM AD was established with the Decision for division of the State Power Supply Company "Power Supply Company of Macedonia", Skopje, No.23-3343 / 1 dated 27.09.2004 adopted by the Government of the Republic of Macedonia, on the basis of the Law on Transformation of the Power Supply Company of Macedonia. ${ }^{21}$ In fact, this company was one of the legal successors of "JP Power Supply Company" in state ownership, Skopje, and the same in the legal circulation participated and worked under a company: Power Supply Company of Macedonia, Joint Stock Company for Distribution and Supply of Electricity, in state ownership, Skopje or abbreviated AD ESM.

With the Sale Purchase agreement in April 2006, "ESM AD" became the property of the EVN AG group from Austria, and with the rebranding in 2008 this company received its final name "EVN Macedonia AD Skopje."

The privatization of this sector arises from the well-known notion that the private capital in a market circumstances, allocates more efficiently the resources which lead to a cheaper market price of the product. Certainly, it took a while in order for this to happen.

With the independence of the Republic of Macedonia and the collapse of the centralized electricity market, the country has shown aspirations towards the EU and thereof the country

\footnotetext{
${ }^{221}$ Bushi Lazo, The Perspectives of the electric power in Republic of Macedonia, Struga 2005
} 
had to reach gradually to a certain level of modernization of all aspects that encompass the energy sector.

More than certain, the experience was drawn from the European countries, that is, from countries that were already EU members and in one way or another, their legislation in reference to energy was harmonized to EU standards. In March 2006, the privatization of "ESM distribution" was completed.

With the entry of EVN in Macedonia, the country stepped forward to the EU integration. The entering of the company EVN on the Macedonian market opened many opportunities for entering of other investments in the country.

The sale of ESM went through a process of opposition, skepticism and disagreement by citizens and experts, but the final outcome was to achieve development of the energy sector of the Republic of Macedonia. The sale of ESM was one of the most controversial processes and it was conducted through a public announcement, at which several companies applied and at the end of the election, the number was reduced to 3 companies: ENEL from Italy, CEZ from Czech Republic and EVN from Austria. The Austrian company EVN was the one that bided over the competitors and won the battle for the purchase of the Macedonian Power Supply Company.

In 2006, immediately after the privatization of EVN Macedonia, EVN AG followed a process of complete reorganization of the company, which until then was in a bad state. This bad situation meant fee collection problems, electricity losses, poor quality of infrastructure, poor financial results, and a number of other negative indicators that began to be changed thoroughly and systematically after the privatization. Much attention has been paid to the financial investments, modern organizational and management layout, structure and the use of the latest technological advancements in the power industry. Following these measures, the image of the company, as well as the results of the work, changed completely.

With successful reorganization and transformation, EVN Macedonia has created a solid basis for accomplishment of the set goals and management of all the challenges in the future. EVN's goal was to improve the conditions and service for consumers, and then improve the supply. By separating the sector of generating, the sector of distribution faced the most difficult task-to discipline the consumers to pay regularly their duties, to suppress the illegal consumers of electricity and to reduce commercial losses.

EVN Macedonia is a company whose main activity is distribution and supply of electricity in the Republic of Macedonia.

\section{Power Generating capacities in Republic of Macedonia}

The Republic of Macedonia, as a country that has long been going through a transition period, a period in which energy resources, both in terms of generating and in terms of electricity transmission, were at a centralized level, has constantly been working on the improvement of the energy sector and the electricity market. For that purpose, hydropower plants, thermal power plants, and even lately, wind power plants were built. 
The larger part of the existing energy infrastructure in Macedonia was built during the secondhalf of the last century. ${ }^{22}$ Although new facilities have been opened in the last two decades, still they were not enough to meet the growing demand for energy or to strengthen Macedonia's energy position in the region of south-eastern Europe.

However, from the aspect of a successful economy, one should take into account the most efficient way of power generating. Although the thermal power plants are the largest and most suitable for the most power generating, for the Republic of Macedonia this mode of power generating is more inconvenient than the production of electricity through hydropower plants.

This is due to the fact that the power generating through thermal power plants is more difficult to control and it is necessary to plan in advance the amount of electricity required to be generated, something that is difficult to predict in a country like Republic of Macedonia, because in conditions in which the energy sector is still underdeveloped, Macedonia cannot afford to suffer losses.

Talking about the method of power generating, windmills as a way of producing electricity in the Republic of Macedonia is considered to be unsuitable method, primarily because there is no wind in the Republic of Macedonia, but it is also necessary to pay attention to many other factors on which the success of such a large investment depends on. The factors that the success of such an investment will depend on are: the legislative framework that needs to regulate this area, further development of the infrastructure that implies building of new roads to reach the windmills, facilities that will maintain the windmills, etc. In the Republic of Macedonia there are only two windmills, one of which is located in Bogdanci, and the other is located in Ovche Pole.

The forecasts are that according to the listed factors, this investment of the Republic of Macedonia will be profitable for the country after 20 years, which period is quite long. Both the hydro and thermal power plants built in the last century are the skeleton of the system for power generating and the core of the Macedonian energy stability. However, in the last 20 years, the level of investment in power generating facilities has fallen sharply. The last important investment that was made in this sector was the construction of the Kozjak hydroelectric power plant, released for use in 2004, and whose construction lasted 10 years. ${ }^{223}$ Since then, there are no new investments for the construction of hydro, nor for the construction of thermal power plants. Unlike the power generating system, in the last few years large investments have been made in the power transmission system, which investments are parts of the broader scheme for regional connection of the power systems from the countries in south-eastern Europe.

\section{Republic of Macedonia as part of the European Energy Community}

In accordance with the European trends and developments, Republic of Macedonia has always strived to reach the level of development of the energy sector and worked on its continuous improvement. The Republic of Macedonia became a signatory of the Energy Community Treaty, which came into force in July 2007. Republic of Macedonia moved one step forward and made an important step with the ratification of the CEFTA membership agreement in May. The progress that has been achieved with regard to the security and stability of energy supply is certified by the Energy Law, which was adopted in May 2006 and it envisaged the preparation and designing of a Strategy for long-term development of the energy sector. The ratification of

\footnotetext{
222 Forum Analitika, September, 2009

${ }^{223}$ Analitika, September, 2009
} 
the Treaty establishing the Energy Community paved the way for progress to be made regarding the internal energy market. In the context of this progress, and according to the (at that time) Energy Law, the energy policy, the regulatory body, the construction of new facilities, the electricity market, the natural gas market, the oil and oil derivatives market, the issuance of licenses, energy efficiency and renewable sources of energy, were regulated.

Although the Republic of Macedonia has made significant progress in parts of the energy sector, especially with regard to the legislation on the internal energy market, yet the whole process of energy sector development was very slow and there was a need of additional adoption of bylaws, which by-laws had to be harmonized with the Law on energy and new trends. Most of the processes happened because of the signing and ratification of the Energy Community Treaty for the Republic of Macedonia that required meeting of certain obligations.

The Republic of Macedonia has consistently worked to promote and reform its energy sector as well as those sectors related to the energy sector and to meet the requirements arising from the Energy Community. The Energy Community Secretariat, as the only permanent institution of the Energy Community, reviews the implementation of the Treaty by the contracting parties and prepares an Annual Report that gives a realistic picture of the progress that has been made in this area. In case of certain non-compliance by one Contracting Party based on the legislation of the Energy Community, there is a possibility the non-complying Contracting Party to be brought in front of the Council of Ministers. In this context, several cases have been raised against the Republic of Macedonia on several occasions that have tackled the field of energy law. Regarding cases of non-compliance, Macedonia had the first case in 2008 in the field of electricity that was closed after the adoption of the new Energy Law in 2011, which managed to remedy the situation.

The second case, which is very important for the development of the energy sector, is the case of electricity from 2015, and it concerns the delaying of the full opening of the electricity market, which means for small businesses and households. The long-awaited full liberalization of the electricity market was suddenly postponed and small businesses and households were deprived of the opportunity to buy electricity directly from the supplier who they would choose by themselves.

\section{Chronology of the Law on Energy}

It seemed that the legal and economic reforms in the country could not keep up with the development of the energy sector, since they were in constant competition to comply with the number of investments in the Macedonian energy sector. The first Law on Energy of the Republic of Macedonia was adopted on September 10, 1997, that was later amended and complemented several times. Then, on May 11, 2006, the second Law on Energy was adopted, but as a consequence of the reforms in the field of energy and the need to adjust the Macedonian legislation with the European legislation the adoption of a new Law on Energy happened on February 3, 2011, and finally as a consequence of the tendency for liberalization of the electricity market a new Law on Energy was enacted on May 21, 2018. Thus the energy sector of Republic of Macedonia continues to develop but this development needs to be carried out very carefully, as if there would not be another unsuccessful attempt to liberalize the electricity market. 


\section{Conclusion}

As a summary from the points presented herein, it can be concluded that Republic of Macedonia has undergone a long process of development of the energy sector, constantly following the example of the European countries. There is no doubt that this is a matter that deserves a wide elaboration and which, without a doubt, represents a complex framework. It is obvious that Macedonia has worked a lot on reforming its energy sector, developing energy law and related areas in order to comply with the legislation of the Energy Community. In this regard, the fact that Macedonia has made progress is obvious, but the identified problems show that there is still a lot of work to do. There are many challenges that the country should overcome before it meets the standards of the Energy Community and thus improve the standard of living of its citizens.

In this context, it must be noted that the energy law and its legal framework must show a certain amount of flexibility and rationality, in order to be able to adapt to the upcoming trends and innovative solutions. None of the markets is perfect, and therefore neither the electricity market, so that is why it constantly needs to be developed and be responsive to the arising needs. Therefore, it is necessary to work constantly on the promotion and development of the market.

Legal and economic reforms in the country seem as not being able to follow the development of the energy sector, so this is why when we are talking about the energy market; we need good, transparent legislation and a regulatory framework, which will incorporate European standards that must be functional and implemented. A serious approach to the protection of foreign investors is required, as well as simplification of procedures for issuing work permits and real opening of the markets for electricity and natural gas. The central problem remains to be the efficiency of the public administration, whose capacity needs to be improved by introducing continuous trainings, but there is also a need of building of an electronic database and connection of all institutions to a single electronic network and related.

\section{References}

1. Bushi L. The Perspectives of the electric power in Republic of Macedonia, Struga 2005

2. Bushi, L. The Electrical Power in Republic of Macedonia, Struga, 2004

3. 60 years electrification of Skopje

4. Eighty years of constant rise

5. Kubasek K. Nancy, Silverman Garys, environmental law, eight edition, 2014

6. Law on transformation of Power Supply Company of Macedonia, Joint Stock Company for power generating, transmission and distribution in state ownership, Official Gazette of RM 19/2004

7. „Forum Analitika“, September, 2009

8. http://mepso.com.mk/

9. http://www.elem.com.mk/

10. https://www.elektrodistribucija.mk/About-us.aspx

11. povijest.hr/nadanasnjidan/prva-edisonova-elektricna-mreza-u-new-yorku-1882/

12. http://www.tesla.org.rs/locations/hidroelektrana-na-nijagarinim-vodopadima 